Review

\title{
Prospects of Therapeutic Target and Directions for Ischemic Stroke
}

\author{
Jung Hak Kim ${ }^{1,+}$, So Young Kim ${ }^{2,+} \mathbb{D}$, Bokyung Kim ${ }^{3} \mathbb{D}$, Sang Rae Lee ${ }^{4}$, Sang Hoon Cha ${ }^{5,6}$ and Dong Seok Lee ${ }^{3} \mathbb{D}$ \\ and Hong Jun Lee ${ }^{1,5, *}$
}

check for updates

Citation: Kim, J.H.; Kim, S.Y.; Kim, B.; Lee, S.R.; Cha, S.H.; Lee, D.S.; Lee, H.J. Prospects of Therapeutic Target and Directions for Ischemic Stroke. Pharmaceuticals 2021, 14, 321. https://doi.org/10.3390/ph14040321

Academic Editors: Lusine Danielyan and Huu Phuc Nguyen

Received: 5 March 2021

Accepted: 28 March 2021

Published: 1 April 2021

Publisher's Note: MDPI stays neutral with regard to jurisdictional claims in published maps and institutional affiliations.

Copyright: (c) 2021 by the authors. Licensee MDPI, Basel, Switzerland. This article is an open access article distributed under the terms and conditions of the Creative Commons Attribution (CC BY) license (https:// creativecommons.org/licenses/by/ $4.0 /)$.
Research Institute, e-biogen Inc., Seoul 07282, Korea; jnhkim1116@gmail.com

2 College of Medicine, Chung-Ang University, Seoul 06974, Korea; biochemcau@naver.com

3 BK21 FOUR KNU Creative BioResearch Group, School of Life Sciences, Kyungpook National University, Daegu 41566, Korea; mideun@knu.ac.kr (B.K.); lee1@knu.ac.kr (D.S.L.)

4 Laboratory Animal Research Center, Department of Pharmacology, School of Medicine, Ajou University, Suwon 16499, Korea; lsr21@ajou.ac.kr

5 College of Medicine and Medical Research Institute, Chungbuk National University, Cheongju 28644, Korea; shcha@chungbuk.ac.kr

6 Department of Radiology, Chungbuk National University Hospital, Cheongju 28644, Korea

* Correspondence: leehj71@gmail.com or leehj71@chungbuk.ac.kr

$\dagger$ These authors contributed equally to this work.

Abstract: Stroke is a serious, adverse neurological event and the third leading cause of death and disability worldwide. Most strokes are caused by a block in cerebral blood flow, resulting in neurological deficits through the death of brain tissue. Recombinant tissue plasminogen activator (rt-PA) is currently the only immediate treatment medication for stroke. The goal of rt-PA administration is to reduce the thrombus and/or embolism via thrombolysis; however, the administration of rt-PA must occur within a very short therapeutic timeframe ( $3 \mathrm{~h}$ to $6 \mathrm{~h}$ ) after symptom onset. Components of the pathological mechanisms involved in ischemic stroke can be used as potential biomarkers in current treatment. However, none are currently under investigation in clinical trials; thus, further studies investigating biomarkers are needed. After ischemic stroke, microglial cells can be activated and release inflammatory cytokines. These cytokines lead to severe neurotoxicity via the overactivation of microglia in prolonged and lasting insults such as stroke. Thus, the balanced regulation of microglial activation may be necessary for therapy. Stem cell therapy is a promising clinical treatment strategy for ischemic stroke. Stem cells can increase the functional recovery of damaged tissue after post-ischemic stroke through various mechanisms including the secretion of neurotrophic factors, immunomodulation, the stimulation of endogenous neurogenesis, and neovascularization. To investigate the use of stem cell therapy for neurological diseases in preclinical studies, however, it is important to develop imaging technologies that are able to evaluate disease progression and to "chase" (i.e., track or monitor) transplanted stem cells in recipients. Imaging technology development is rapidly advancing, and more sensitive techniques, such as the invasive and non-invasive multimodal techniques, are under development. Here, we summarize the potential risk factors and biomarker treatment strategies, stem cell-based therapy and emerging multimodal imaging techniques in the context of stroke. This current review provides a conceptual framework for considering the therapeutic targets and directions for the treatment of brain dysfunctions, with a particular focus on ischemic stroke.

Keywords: ischemic stroke; biomarkers; microglia activation; stem cell therapy; multimodal imaging

\section{Introduction}

Stroke is a serious, adverse neurological event and the third leading cause of death and disability worldwide. Recently, the number of stroke patients is increasing due changing lifestyles and the aging population [1]. Most strokes are caused by a block in cerebral blood 
flow, resulting in neurological deficits through the death of brain tissue. Stroke can be divided into two subtypes: ischemic and hemorrhagic [2,3]. Hemorrhagic stroke is caused by the vascular rupture of a cerebral artery or vein in the brain, causing localized bleeding in the surrounding tissue. Two main types of hemorrhagic stroke have been classified: intracerebral and subarachnoid. Subarachnoid hemorrhage is characterized as a stroke that occurs as a result of saccular aneurysms interrupting the subarachnoid space. On the other hand, hemorrhagic stroke accounts for approximately $10 \%$ to $15 \%$ of all stroke cases, with a mortality rate of $40 \%$ to $50 \%$ after the onset of the disease [4]. Ischemic stroke occurs as a result of an obstruction of blood flow in the cerebral artery stemming from a thrombus or embolus, hypoperfusion from decreased blood pressure, or a reduction in oxygen levels due to systemic hypoxia. Collectively these represent the most common causes of cerebrovascular events, such as transient ischemic attack (TIA). Ischemic stroke accounts for $85 \%$ to $90 \%$ of all types of stroke [5]. Common risk factors for stroke are widely related to hypertension, dyslipidemia, abdominal obesity, alcoholism, heart disorders, diabetes, and smoking, all of which affect a large number of individuals. In addition, other risk factors, including atrial fibrillation, TIA, and the microglia associated inflammatory response are well known risk factors for stroke [6-8].

The immediate treatment goals in most ischemic stroke cases are focused on stabilizing the patient and rapidly recovering cerebral blood flow. This requires a quick assessment before treatment and early intervention to restore maximal reperfusion of brain tissue [9].

Previous studies have reported that recombinant tissue plasminogen activator (rt-PA) is the only effective acute treatment option for ischemic stroke patients that has been approved by the United States Food and Drug Administration. The primary mechanism of this agent is the reduction in thrombi and emboli by thrombolysis. However, rt-PA must be administered within a very short therapeutic timeframe ( $3 \mathrm{~h}$ to $6 \mathrm{~h}$ ) after the onset of acute stroke symptoms [10-13]. Based on several clinical trials, administration of intravenous rt-PA within $3 \mathrm{~h}$ of the onset of symptoms is the recommended method of treatment for eligible patients who experience ischemic stroke.

The goal of endovascular thrombectomy is to expand the thrombolytic therapeutic time after symptom onset by rapidly recanalizing the interrupted blood vessels and restoring tissue perfusion, with the hope that early brain tissue reperfusion can prevent brain cells from being damaged [14-18]. Nevertheless, the widespread use of this medication for thrombolytic therapy is limited and cannot protect against neuronal cell death within the brain tissue during the acute phase of the disease [19]. Moreover, the risk of severe hemorrhagic complications limits rt-PA treatment to a small percentage of ischemic stroke patients [20]. Although neuroprotective therapies, and other approaches including erythropoietin, $\mathrm{N}$-methyl d-aspartate antagonists, and gamma-aminobutyric acid, have shown some potential in preclinical acute stroke trials, the effectiveness of such treatments has not been demonstrated in clinical trials [21,22]. Thus, to improve functional recovery, the development of novel treatment strategies with an expanded therapeutic window after acute stroke is required. This review aims to provide a conceptual framework for considering the therapeutic targets and directions for treatment of brain dysfunction, with a particular focus on ischemic stroke.

\section{Microglia Related Neuroinflammation in Ischemic Stroke}

Microglia are the primary resident immune system cells, and they play a key role in the maintenance of the central nervous system (CNS) [6]. Microglia maintain the quiescent state, stimulating the typically thin ramified processes that occur in a normal healthy environment [23]. They recognize various external stimuli such as glycoproteins, aggregated proteins, cytokines, chemokines and the inflammatory microenvironment [24]. When microglia detect a broad range of stimuli from an infection, toxic chemical, ischemia or brain injury, they migrate into lesions and transform into several different functional activated forms with different morphologies, producing different cytokines and receptors $[6,25]$. Several studies have shown that microglia cells regulate the neuroinflammatory response 
after ischemic stroke [26,27]. After ischemic stroke, microglia cells are activated and release inflammatory cytokines such as interleukin- $1 \beta$, tumor necrosis factor- $\alpha$, interleukin-6 [28]. Microglia can adopt three different activation morphologies: M1 (classically activated macrophages), M2 (wound-healing macrophages) and regulatory macrophages via induction by different stimuli [29]. M1 activation of microglia occurs by induction of interferon- $\gamma$ $(\mathrm{IFN}-\gamma)$ and tumor necrosis factor (TNF) and induces the secretion of pro-inflammatory mediators such as IL-6, IL-12 and IL-23 from microglia [30,31].

M2 activation of microglia is triggered by the cyclic AMP response element binding protein (CREB) and the $C / E B P \beta$ transcription factor, which not only induces the secretion of IL-4, IL-10, TGF- $\beta$ and neuroprotective factors, but also stimulates the initiation of chronic inflammatory processes (tissue repair) that inhibit pro-inflammatory responses $[32,33]$

Regulatory macrophages are involved in the late stage of the adaptive immune response. These cells arise via the stimulation of glucocorticoids (from adrenal cells in the hypothalamic-pituitary-adrenal (HPA) axis), immune complexes, prostaglandin, apoptotic cells and IL-10. After stimulation, these cells upregulate the production of IL-10 and downregulate IL-12, while also inhibiting the production of pro-inflammatory cytokines (Figure 1) [34]. Microglia activation has been correlated with the development of agerelated neuroinflammatory neurodegenerative conditions including neuroinflammation Alzheimer's disease, Parkinson's disease, dementia correlated with the human immunodeficiency virus, and age-related macular degeneration (AMD) [23]. In aged human brains, age-related abnormalities in the cytoplasmic structure of sporadic microglial cells have been shown to appear. Such abnormalities are termed "microglial dystrophic" features and are characterized by reduced dendritic complexity with increased residual processes being observed, including tortuosity, cytoplasmic beading, and fragmentation, reflective of the ongoing cytorrhexis [35]. Microglia activation displays functional abnormalities, including increased levels of pro-inflammatory cytokines and reactive oxygen species, in addition to increased mitochondrial contents compared to young microglia [36].

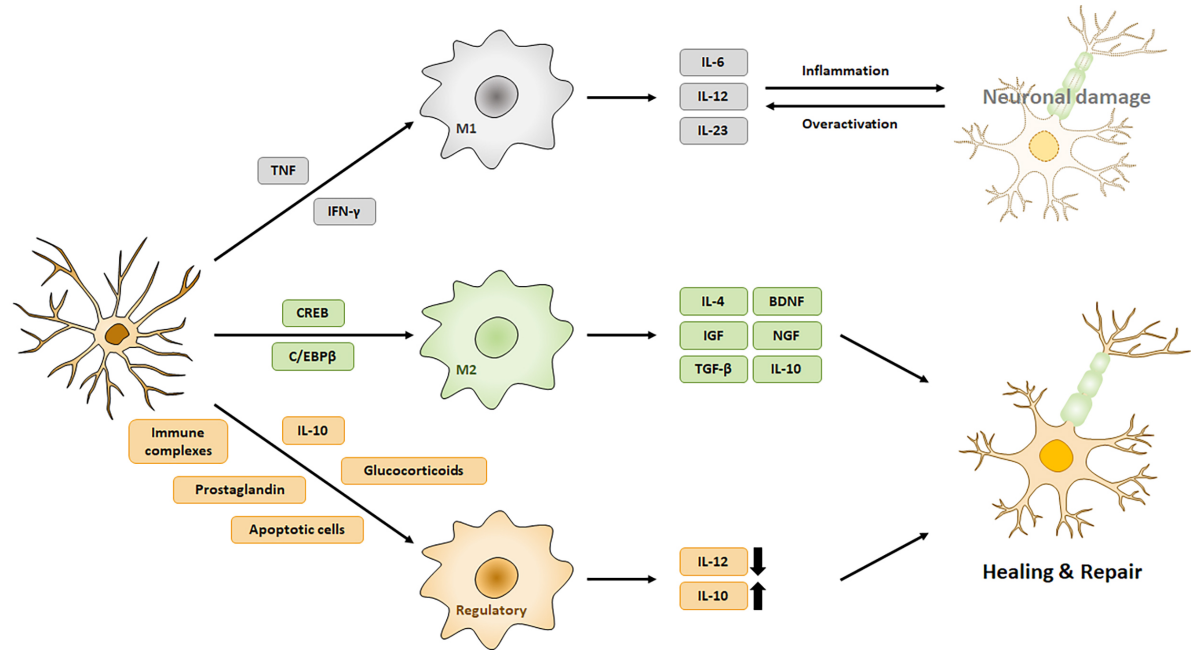

Figure 1. Microglia activation patterns and related factors. Neuroinflammation produce various environmental stimuli after ischemic stroke. Microglia change their morphology through different environmental stimuli and produce various pro- or anti-inflammatory factors.

Furthermore, it has been found that aged microglia express increased levels of inflammatory cytokines, such as interleukin- $1 \beta$, tumor necrosis factor- $\alpha$, and interleukin- $6[37,38]$. These findings indicate that aged microglia may contribute to the neuroinflammation state, which is related to enhanced susceptibility of the aged CNS systemic environment to neurodegenerative disease.

The neurotoxic effects of microglia activation become progressively worse in neurodegenerative diseases. Inflammatory triggers mediate these neurotoxic effects both directly on the neurons and indirectly via the over-activation of microglia. Pro-inflammatory molecules 
produced from microglia enhance neurotoxicity in neurons, which results in the cumulative influence of environmental insults such as microglial activators (laminin, MMP3, etc.). These activators lead to severe neurotoxicity by over-activation of microglia in prolonged and lasting insults such as stroke [39]. Inflammation induces neurotoxicity in neurodegenerative diseases such as stroke and promotes microglial activation, leading to microglial dysregulation and over-activation. Microglia activation has a bi-lateral effect for neuronal survival and death in cerebral ischemia. In the degenerative environment of cerebral ischemia, several factors are recognized as pathogenic signals by microglia and these lasting pathogenic signals lead to progressive and cumulative neurotoxicity by microglial over-activation. Both the pro- and anti-inflammatory effects of microglia are necessary for initiating recovery systems following a stroke. However, the balanced regulation of microglial activation is poorly understood. Delineating the controlling mechanism of microglial activation may be necessary for improving therapy for stroke patients in future studies.

\section{Pathophysiology and Biomarkers in Ischemic Stroke}

The pathological mechanisms of stroke include energy failure, oxidative stress, disruption of the blood-brain barrier (BBB), neuro-excitotoxicity, brain inflammation, microglial activation, and endothelial injury. Previous clinical studies have emphasized the importance of understanding these mechanisms in order to diagnose and manage ischemic stroke [40-42].

Ischemic stroke is commonly characterized as the rapid interruption of blood supply, leading to failed neurological function resulting from oxygen deprivation and glucose delivery to the brain tissue [14,43]. During brain ischemia, cerebral blood flow is significantly decreased (by approximately 6-14 $\pm 2 \mathrm{~mL} / 100 \mathrm{~g} / \mathrm{min}$ ) which leads to the induction of pathological processes [44]. During these processes, the ischemic penumbra exhibits structurally reversible features resulting from the ischemic event-generally defined as the hypoperfused area [45]-and represents a clinical target for ischemic stroke therapy. Strokeinduced angiogenesis occurs in the peri-infarct regions and ventricular/subventricular zone (V/SVZ) of the lateral ventricles [46]. Furthermore, stroke-induced neurogenesis occurs in the V/SVZ and in the subgranular zone of the dentate gyrus, a neural stem cell region [47]. In the V/SVZ region, neural stem cell proliferation generated by a stroke is involved in the stimulation of cerebral endothelial cells $[46,48]$.

Biomarkers could be a valuable component of diagnostic assessment approaches and guide treatment and prognosis. Thus, stroke biomarkers could improve treatment by enabling the early diagnosis and facilitating sequential monitoring of patients, in addition to providing a rapid assessment of the severity of brain damage [49-51]. The use of these diagnostic biomarkers in the pathophysiological processes of a stroke would be particularly important in patients with non-localized or transient neurological symptoms [49-51]. An example of a glial-specific biomarker of acute brain injury is the S100 calcium-binding protein B (S100B), a common astrocytic marker [52] with important roles in $\mathrm{Ca}^{2+}$ homeostasis, astrocyte glutamate uptake, and neurite outgrowth stimulation [53]. However, $\mathrm{S100B}$ as a prospective marker is elevated in ischemic stroke, as is glutamate excitotoxicity and astrogliosis, which commonly occur in cases of trauma and traumatic brain injury [54,55]. Glial fibrillary acidic protein (GFAP) is a brain specific type III intermediate filament protein that is expressed by mature astrocytes and some other glial cells [56]. Several aspects of brain injuries and neurological disorders involve gliosis and the induction of GFAP, which has been proposed as a biomarker of glial injury in stroke $[57,58]$. As important indicators of brain damage, ubiquitin C-terminal hydrolase-L1, myelin basic protein, neuron-specific enolase have been studied [59-62]. In addition, fibronectin, Ddimer and von Willebrand factor have been associated with ischemic stroke and are known as biomarkers that are involved in coagulation and thrombosis [63-65]. Laskowiz et al. described a panel of diagnostic biomarkers in stroke including S100B, von Willebrand factor, 
matrix metalloprotease-9, B-type nerve growth factor and MCP-1 [66]. These are intimately involved in ischemic stroke and, therefore, can be used as potential biomarkers (Table 1).

During ischemic stroke, oxidative stress from free radicals, such as superoxide anions, hydroxyl radicals, hydrogen peroxide and nitric oxide, is closely related to brain tissue injury $[67,68]$. These free radicals, as potential indirect biomarkers of oxidative stress, are associated with increased $\mathrm{Ca}^{2+}$ levels, disruptions in mitochondrial integrity in ischemia and reperfusion, and-ultimately-lead to cell death [69-71]. Importantly, 8-hydroxy-2'deoxyguanine, a product of DNA oxidation, has been widely proposed as a biomarker of oxidative damage in stroke patients [72,73]. Ischemic stroke is extremely complex and is reflected in post-ischemic inflammation, involving endothelial cells, astrocytes, microglia and neurons $[74,75]$. During ischemic inflammation, upregulation of $\mathrm{Ca}^{2+}$ levels, free radicals and secretion of proinflammatory cytokines such as interleukin- 1 , tumor necrosis factor- $\alpha$ and interleukin- $1 \beta$, as well as neuroprotective factors including erythropoietin, transforming growth factor $\beta 1$, and metallothionein-2, has been reported [76-78]. Biomarker measurement could be performed during the onset of initial symptoms, enabling expedited treatment of high-risk patients, potentially facilitating early stroke recovery. Presently, various ischemic stroke candidate biomarkers are being examined; however, none are currently being investigated in clinical trials and, thus, further studies are needed.

\section{Application of Stem Cell Therapy in Stroke}

Cell-based therapy is an emerging and promising new therapeutic strategy for enhancing tissue repair and neurological recovery in ischemic stroke patients $[79,80]$. The primary objective of cell-based therapies is to restore or replace damaged tissue with functional cells, with the final aim of integrating these cells with the remaining functional original cells and supporting the restoration of lost organ function. Recent studies have suggested that stem cells can increase the functional recovery of damaged tissue in post-ischemic stroke through various mechanisms, including stem cell secretion of neurotrophic factors, immunomodulation, stimulation of endogenous neurogenesis, and neovascularization [81-87].

Previous preclinical studies have reported that stem cell therapy may enhance functional recovery and behavioral improvements in animal models of stroke [82,88]. Numerous researchers have reported on the use of stem cells harvested from various sources including umbilical cord blood cells [89], adipose derived stem cells [90], amniotic fluid stem cells [91], bone marrow endothelial progenitor cells [92], multipotent progenitor cells [93], neural stem cells (NSCs) [94,95] and induced pluripotent stem cells [96]. Other investigators have selected mesenchymal stem cells (MSCs) for treatment of neurological disease because these cells are easy to collect in large numbers for clinical use. These stem cells have been transplanted through various routes in animal models of stroke, leading to recovery of brain impairment and dysfunctions. The therapeutic effects of MSC-based therapy for the treatment of stroke include the promotion of CNS plasticity and neurovascular remodeling, angiogenesis, and immunomodulation [91,97].

The interaction between transplanted MSCs and brain parenchymal cells promotes neurological recovery; this interaction is mediated by intercellular communication through extracellular vesicles released from stem cells [98,99]. Exosomes are an especially important class of extracellular vesicles that are released by MSCs. Previous studies have reported that MSCs release large numbers of exosomes, which leads to the integration of MSCs with other cells [100]. Exosomes are endosome-derived small membrane vesicles (30 $\mathrm{nm}$ to $100 \mathrm{~nm}$ in size) that are secreted into the extracellular space by cells [101]. They are located in the blood and cerebrospinal fluid, and play important roles in intercellular communication by transferring cargo between source and target cells [101,102]. Emerging data indicate that exosomes released from MSCs have therapeutic effects in stroke and traumatic brain injury by regulating the microenvironment surrounding the brain $[103,104]$. In addition, exosomes transfer their microRNAs (miRNAs) from mesenchymal stromal cells to neuronal cells [105], with MSC-derived exosomes including more than 700 miRNAs that interact with argonaute 2, a component of the RNA induced silencing complex [106,107]. 
The effects of manipulating MSC-derived exosomes to produce and transport increased levels of miRNAs in brain tissue replacement after stroke have been investigated both and [108]. Moreover, investigations into the advantages of exosomal therapies in promoting brain repair processes after ischemic stroke may enhance stroke recovery and lead to the development of novel therapies. Despite fascinating preclinical studies of the STAIR (stroke Therapy Academic Industry Roundtable) criteria using these cell types to repair brain damage, clinical trial is underway and is still the initial stages. Furthermore, stem cell-based therapies are associated with ethical issues, and transplantation of iPSC (induced Pluripotent Stem Cell) is accompanied with the risk of teratoma formation [109-112]. Thus, the precise mechanisms of the host's response after treatment with these therapies, in addition to the fate of donor cells, require further investigation.

\section{Imaging Techniques for Stem Cell Therapy}

Current diagnostic tests for stroke rely on neurological assessments using various neuroimaging modalities. As stroke types (i.e., ischemic versus thrombotic) clearly differ, knowledge of these clinical differences is very important in stroke treatment approaches. Distinguishing between the clinical differences in stroke types has been facilitated by the application of diagnostic imaging systems including computed tomography (CT) and magnetic resonance imaging (MRI) [113]. Advances in imaging techniques to classify stroke have been rapid and, in part, prompted by the need for improved clinical approaches. Currently, imaging methods and other investigative methods are combined to facilitate the tracking of stem cell transplantation in stroke patients, including MRI, nuclear medicine imaging and OI (Optical Imaging) [114].

To adequately investigate stem cell therapies for neurological diseases in preclinical studies, it is very important to develop imaging technologies that are able to evaluate disease progression by "chasing" (i.e., tracking or monitoring) transplanted stem cells in recipients. The pathology of stroke and regeneration by transplanted stem cells develop through either endogenous or exogenous mechanisms, which can be assessed using various imaging technologies, including traditional tissue staining, immunohistochemistry, autoradiography, electrophysiological analysis, and molecular biological methods [115,116].

Most traditional evaluation methods, such as immunohistochemistry and molecular biological techniques, have been useful tools for assessing disease progress only in preclinical studies because these techniques are only able to analyze post-mortem or collected tissues. Many studies have described changes in infarct volume due to stroke in middle cerebral artery occlusion animal models using tissue staining with 2,3,5-triphenyltetrazolium chloride, and post-stroke neural cell loss evaluated using the "TUNEL" assay [90,93,117]. Some researchers have used electron microscopy as tool to observe the repair of the BBB (Bloodbrain-barrier) system and to track transplanted stem cells $[92,118,119]$. However, these technologies only use post-mortem samples, not live animals or human subjects. Using molecular analyses, researchers can determine alterations in gene or protein responses induced by stroke, such as upregulation of GLT-1 and vascular endothelial growth factor, and reductions in peri-ischemic extracellular glutamate [120,121], in addition to reductions in the inflammatory responses $[93,96]$ of stem cells. Immunofluorescence staining facilitates the visualization of the induction of several neuron types and different blood vessels $[117,122,123]$.

In more recent stroke studies, the importance of developing more sensitive and noninvasive OI technologies has been highlighted. MRI and CT are the common imaging modalities used by clinicians. Fluorescence, bioluminescence and nanoparticle imaging have been developed to generate more sensitive data, support the diagnosis of ischemic stroke pathology, such as infarct size and hemorrhage, and the restore cerebral blood flow, and enable the tracking of engrafted stem cells using CT and MRI as non-invasive methods [124,125]. Accordingly, some researchers have used MRI [89,119,126] or positron emission tomography-CT $[127,128]$ to evaluate infarct volume in live animals. Nanopar- 
ticle technology is able to detect and chase transplanted stem cells using MRI in live animals $[119,129,130]$.

Superparamagnetic iron oxide nanoparticles (SPION) have been labeled with stem cells from various sources such as NSCs (Neural Stem cell), BMSC (Bone Marrow Stem Cell), MSCs (Mesenchymal Stromal Cell), embryonic stem cells (ESCs) in order to chase the survival, migration and integration of transplanted stem cells in animal ischemic stroke models via MRI [131-138]. Organic fluorescent nanoparticles with aggregationinduced emission also represent good tracking particles. MSCs have been transplanted into a rat ischemia model after fluorescent nanoparticles labeling. These nanoparticles have low cytotoxic effects and do not affect the normal function of MSCs $[139,140]$. These nanoparticles have been used to perform multiple tasks, not only related to detecting stem cells themselves, but also to delivering effective drugs. Recent studies have demonstrated that stem cells promote neurogenic, neuroprotective and vasculogenic properties, while they are also capable of producing therapeutic effects and stimulating the creation of a microenvironment, using nanoparticles, via the delivery the therapeutic agent, retinoic acid (RA) [141], antioxidant [142] and chemoattractant [143].

Fluorescence imaging visualizes light emitted by green fluorescent proteins or emission fluorescent dyes such as DiI, DiO and CMFDA (5-Chloromethylfluorescein diacetate) in anesthetized animals [144-146]. Bioluminescence imaging visualizes photons emitted by luciferase enzyme reactions in live animals. To enable bioluminescence imaging, however, stem cells must be genetically modified to express the luciferase enzyme before transplantation $[147,148]$ Stem cells can be labeled with nanoparticles such as superparamagnetic iron oxide nanoparticles, quantum dots, and pebbles in order to chase transplanted stem cells using MRI [149-151]. One study suggested the use of NSCs for the treatment of neurological diseases in a nonhuman primate stroke animal model. In this study, magnetic labeled transplanted human NSCs, chased using MRI, survived for 2 years in the nonhuman primate brain without immunosuppression and, moreover, differentiated into neurons without tumorigenesis [94] (Table 1).

Table 1. Investigation of reported ischemic stroke Biomarkers.

\begin{tabular}{|c|c|c|c|c|}
\hline Biomarker & $\begin{array}{l}\text { Role in Ischemic } \\
\text { Stroke }\end{array}$ & Description & $\begin{array}{l}\text { Application to } \\
\text { Ischemic Stroke }\end{array}$ & Reference \\
\hline $\mathrm{S} 100 \beta$ & Glial damage & $\begin{array}{l}\text { Calcium binding protein, } \\
\text { regulation of cell cycle } \\
\text { progression and } \\
\text { differentiation. }\end{array}$ & Diagnosis, stroke severity & [152-154] \\
\hline GFAP & Glia protein & $\begin{array}{l}\text { Intermediate filament proteins } \\
\text { of mature astrocytes }\end{array}$ & Diagnosis & {$[155,156]$} \\
\hline MBP & Glial damage & $\begin{array}{l}\text { The most abundant protein } \\
\text { components of myelin } \\
\text { in the CNS }\end{array}$ & Diagnosis & {$[157,158]$} \\
\hline NSE & Neuronal damage & $\begin{array}{l}\text { Neurotrophic and } \\
\text { neuroprotective properties on } \\
\text { a broad spectrum of CNS }\end{array}$ & Diagnosis & {$[159,160]$} \\
\hline Fibronectin & Hemostasis & $\begin{array}{l}\text { A glycoprotein of extracellular } \\
\text { matrix, binds to integrins } \\
\text { collagen, fibrin }\end{array}$ & Diagnosis, Stroke risk & {$[161,162]$} \\
\hline D-dimer & Hemostasis & Fibrin degradation product & Diagnosis & {$[160,163]$} \\
\hline vWF & Hemostasis & $\begin{array}{l}\text { A blood glycoprotein involved } \\
\text { in hemostasis }\end{array}$ & Diagnosis & {$[164,165]$} \\
\hline MMP9 & Inflammation & $\begin{array}{l}\text { Zinc-metalloproteinases family } \\
\text { involved in the degradation of } \\
\text { the extracellular matrix }\end{array}$ & Diagnosis & [166] \\
\hline MCP1 & Inflammation & $\begin{array}{l}\text { A small chemokine, recruits } \\
\text { monocytes, memory T cells, } \\
\text { and dendritic cells }\end{array}$ & Diagnosis & [167] \\
\hline IL-6 & Inflammation & A pro-inflammatory cytokine & Diagnosis & {$[168,169]$} \\
\hline UCH-L1 & deubiquitinating & $\begin{array}{l}\text { Deubiquitinating enzyme, } \\
\text { highly specific to neurons }\end{array}$ & Diagnosis & [155] \\
\hline
\end{tabular}




\section{Outlook and Conclusions}

Rapid advances are occurring in the development of imaging technologies, with the utilization of more sensitive invasive and non-invasive methods. It is necessary to develop multimodal imaging techniques for the diagnosis of stroke and to evaluate the effects of stem cell therapy. Combining multimodal imaging approaches has compensated for some of the limitations in the currently available methods. Although OI techniques provide direct evidence for the survival, migration, integration and differentiation of stem cells, obstacles to stroke therapy remain, including the development of higher-resolution probes and materials to label stem cells. Both the development and application of non-invasive OI techniques are necessary in order to fully understand stroke progression and the therapeutic potential of stem cells in clinical studies involving human subjects.

During a stroke event, microglia are activated and secrete cytokines, which lead to cell death. To prevent aggravation of the stroke, hyperactivation of microglia needs to be regulated. Thus, many researchers have examined the alterations of various genes in the ischemic region. Such genes are used as biomarkers for stroke diagnosis, which can prevent the serious deterioration of stroke through early diagnosis. Furthermore, biomarkers can represent the basis of stem cell-based therapy as a novel strategy for promoting neurological recovery.

Author Contributions: Conceptualization: H.J.L.; writing—original draft preparation; H.J.L., S.Y.K.; writing - review and editing, J.H.K., B.K.; provided conceptual advice and funding acquisition, S.R.L., S.H.C., D.S.L. All authors have read and agreed to the published version of the manuscript.

Funding: This work was supported by the National Research Foundation of Korea (NRF) grant funded by the Korea government (MSIT) (2016M3A9B6900776).

Institutional Review Board Statement: Not applicable.

Informed Consent Statement: Not applicable.

Data Availability Statement: Not applicable.

Conflicts of Interest: The authors declare no conflict of interest.

\begin{tabular}{|c|c|}
\hline \multicolumn{2}{|c|}{ Abbreviations } \\
\hline \multicolumn{2}{|c|}{ The following abbreviations are used in this manuscript: } \\
\hline $\mathrm{S} 100 \beta$ & S100 calcium-binding protein B \\
\hline GFAP & Glial fibrillary acidic protein \\
\hline MBP & Myelin Basic Protein \\
\hline NSE & Neuron specific enolase \\
\hline vWF & von Willebrand factor \\
\hline MMP9 & Matrix metallopeptidase 9 \\
\hline MCP-1 & monocyte chemoattractant protein- 1 \\
\hline IL-6 & Interleukin 6 \\
\hline UCH-L1 & Ubiquitin C-terminal hydrolase L1 \\
\hline
\end{tabular}

\section{References}

1. Popa-Wagner, A.; Dumitrascu, D.I.; Capitanescu, B.; Petcu, E.B.; Surugiu, R.; Fang, W.-H.; Dumbrava, D.-A. Dietary habits, lifestyle factors and neurodegenerative diseases. Neural Regen. Res. 2020, 15, 394. [CrossRef] [PubMed]

2. Lackland, D.T.; Roccella, E.J.; Deutsch, A.F.; Fornage, M.; George, M.G.; Howard, G.; Kissela, B.M.; Kittner, S.J.; Lichtman, J.H.; Lisabeth, L.D.; et al. Factors influencing the decline in stroke mortality: A statement from the American Heart Association/American Stroke Association. Stroke 2014, 45, 315-353. [CrossRef] [PubMed]

3. Thrift, A.G.; Howard, G.; Cadilhac, D.A.; Howard, V.J.; Rothwell, P.M.; Thayabaranathan, T.; Feigin, V.L.; Norrving, B.; Donnan, G.A. Global stroke statistics: An update of mortality data from countries using a broad code of "cerebrovascular diseases". Int. J. Stroke 2017, 12, 796-801. [CrossRef] [PubMed]

4. Donnan, G.A.; Fisher, M.; Macleod, M.; Davis, S.M. Stroke. Lancet 2008, 371, 1612-1623. [CrossRef]

5. Sommer, C.J. Ischemic stroke: Experimental models and reality. Acta Neuropathol. 2017, 133, 245-261. [CrossRef] 
6. Zhang, W.; Tian, T.; Gong, S.-X.; Huang, W.-Q.; Zhou, Q.-Y.; Wang, A.-P.; Tian, Y. Microglia-associated neuroinflammation is a potential therapeutic target for ischemic stroke. Neural Regen. Res. 2021, 16, 6.

7. Guruswamy, R.; ElAli, A. Complex roles of microglial cells in ischemic stroke pathobiology: New insights and future directions. Int. J. Mol. Sci. 2017, 18, 496. [CrossRef]

8. Whisnant, J.P. Modeling of risk factors for ischemic stroke. The Willis Lecture. Stroke 1997, 28, 1840-1844. [CrossRef]

9. Sloane, K.L.; Camargo, E.C. Antithrombotic management of ischemic stroke. Curr. Treat. Options Cardiovasc. Med. 2019, 21, 1-15. [CrossRef]

10. Thomalla, G.; Sobesky, J.; Kohrmann, M.; Fiebach, J.B.; Fiehler, J.; Weber, O.Z.; Kruetzelmann, A.; Kucinski, T.; Rosenkranz, M.; Rother, J.; et al. Two tales: Hemorrhagic transformation but not parenchymal hemorrhage after thrombolysis is related to severity and duration of ischemia-MRI study of acute stroke patients treated with intravenous tissue plasminogen activator within $6 \mathrm{~h}$. Stroke 2007, 38, 313-318. [CrossRef]

11. Emberson, J.; Lees, K.R.; Lyden, P.; Blackwell, L.; Albers, G.; Bluhmki, E.; Brott, T.; Cohen, G.; Davis, S.; Donnan, G.; et al. Effect of treatment delay, age, and stroke severity on the effects of intravenous thrombolysis with alteplase for acute ischaemic stroke: A meta-analysis of individual patient data from randomised trials. Lancet 2014, 384, 1929-1935. [CrossRef]

12. Wahlgren, N.; Ahmed, N.; Davalos, A.; Hacke, W.; Millan, M.; Muir, K.; Roine, R.O.; Toni, D.; Lees, K.R.; SITS Investigators. Thrombolysis with alteplase 3-4.5 h after acute ischaemic stroke (SITS-ISTR): An observational study. Lancet 2008, 372, 1303-1309. [CrossRef]

13. Arkelius, K.; Vivien, D.; Orset, C.; Ansar, S. Validation of a stroke model in rat compatible with rt-PA-induced thrombolysis: New hope for successful translation to the clinic. Sci. Rep. 2020, 10, 1-12. [CrossRef]

14. Lo, E.H.; Dalkara, T.; Moskowitz, M.A. Mechanisms, challenges and opportunities in stroke. Nat. Rev. Neurosci. 2003, 4, 399-415. [CrossRef]

15. Goyal, M.; Demchuk, A.M.; Menon, B.K.; Eesa, M.; Rempel, J.L.; Thornton, J.; Roy, D.; Jovin, T.G.; Willinsky, R.A.; Sapkota, B.L.; et al. Randomized assessment of rapid endovascular treatment of ischemic stroke. N. Engl. J. Med. 2015, 372, 1019-1030. [CrossRef]

16. Campbell, B.C.; Mitchell, P.J.; Kleinig, T.J.; Dewey, H.M.; Churilov, L.; Yassi, N.; Yan, B.; Dowling, R.J.; Parsons, M.W.; Oxley, T.J.; et al. Endovascular therapy for ischemic stroke with perfusion-imaging selection. N. Engl. J. Med. 2015, 372, 1009-1018. [CrossRef]

17. Berkhemer, O.A.; Fransen, P.S.; Beumer, D.; van den Berg, L.A.; Lingsma, H.F.; Yoo, A.J.; Schonewille, W.J.; Vos, J.A.; Nederkoorn, P.J.; Wermer, M.J.; et al. A randomized trial of intraarterial treatment for acute ischemic stroke. N. Engl. J. Med. 2015, 372, 11-20. [CrossRef]

18. McMeekin, P.; White, P.; James, M.A.; Price, C.I.; Flynn, D.; Ford, G.A. Estimating the number of UK stroke patients eligible for endovascular thrombectomy. Eur. Stroke J. 2017, 2, 319-326. [CrossRef]

19. Patel, R.A.; McMullen, P.W. Neuroprotection in the treatment of acute ischemic stroke. Prog. Cardiovasc. Dis. 2017, 59, 542-548. [CrossRef]

20. Tseng, Y.-J.; Hu, R.-F.; Lee, S.-T.; Lin, Y.-L.; Hsu, C.-L.; Lin, S.-W.; Liou, C.-W.; Lee, J.-D.; Peng, T.-I.; Lee, T.-H. Risk Factors Associated with Outcomes of Recombinant Tissue Plasminogen Activator Therapy in Patients with Acute Ischemic Stroke. Int. J. Environ. Res. Public Health 2020, 17, 618. [CrossRef]

21. Zhang, S.-J.; Luo, Y.-M.; Wang, R.-L. The effects of erythropoietin on neurogenesis after ischemic stroke. J. Integr. Neurosci. 2020, 19, 561-570. [CrossRef] [PubMed]

22. Karsy, M.; Brock, A.; Guan, J.; Taussky, P.; Kalani, M.Y.S.; Park, M.S. Neuroprotective strategies and the underlying molecular basis of cerebrovascular stroke. Neurosurg. Focus 2017, 42, E3. [CrossRef] [PubMed]

23. Wong, W.T. Microglial aging in the healthy CNS: Phenotypes, drivers, and rejuvenation. Front. Cell. Neurosci. 2013, 7, 22. [CrossRef] [PubMed]

24. Fan, Y.; Chen, Z.; Pathak, J.L.; Carneiro, A.; Chung, C.Y. Differential regulation of adhesion and phagocytosis of resting and activated microglia by dopamine. Front. Cell. Neurosci. 2018, 12, 309. [CrossRef]

25. Zhang, S. Microglial activation after ischaemic stroke. Stroke Vasc. Neurol. 2019, 4. [CrossRef]

26. Ma, Y.; Wang, J.; Wang, Y.; Yang, G.-Y. The biphasic function of microglia in ischemic stroke. Prog. Neurobiol. 2017, 157, 247-272. [CrossRef]

27. Pekny, M.; Wilhelmsson, U.; Tatlisumak, T.; Pekna, M. Astrocyte activation and reactive gliosis-A new target in stroke? Neurosci. Lett. 2019, 689, 45-55. [CrossRef]

28. Jayaraj, R.L.; Azimullah, S.; Beiram, R.; Jalal, F.Y.; Rosenberg, G.A. Neuroinflammation: Friend and foe for ischemic stroke. J. NeuroInflamm. 2019, 16, 142. [CrossRef]

29. Kanazawa, M.; Ninomiya, I.; Hatakeyama, M.; Takahashi, T.; Shimohata, T. Microglia and monocytes/macrophages polarization reveal novel therapeutic mechanism against stroke. Int. J. Mol. Sci. 2017, 18, 2135. [CrossRef]

30. Plastira, I.; Bernhart, E.; Goeritzer, M.; Reicher, H.; Kumble, V.B.; Kogelnik, N.; Wintersperger, A.; Hammer, A.; Schlager, S.; Jandl, K. 1-Oleyl-lysophosphatidic acid (LPA) promotes polarization of BV-2 and primary murine microglia towards an M1-like phenotype. J. Neuroinflamm. 2016, 13, 205. [CrossRef] 
31. Ji, J.; Xue, T.F.; Guo, X.D.; Yang, J.; Guo, R.B.; Wang, J.; Huang, J.Y.; Zhao, X.J.; Sun, X.L. Antagonizing peroxisome proliferatoractivated receptorgammaa facilitates M1-to-M2 shift of microglia by enhancing autophagy via the LKB 1-AMPK signaling pathway. Aging Cell 2018, 17, e12774. [CrossRef]

32. Lin, L.; Yihao, T.; Zhou, F.; Yin, N.; Qiang, T.; Haowen, Z.; Qianwei, C.; Jun, T.; Yuan, Z.; Gang, Z. Inflammatory regulation by driving microglial M2 polarization: Neuroprotective effects of cannabinoid receptor-2 activation in intracerebral hemorrhage. Front. Immunol. 2017, 8, 112. [CrossRef]

33. Rehman, S.U.; Ikram, M.; Ullah, N.; Alam, S.I.; Park, H.Y.; Badshah, H.; Choe, K.; Ok Kim, M. Neurological enhancement effects of melatonin against brain injury-induced oxidative stress, neuroinflammation, and neurodegeneration via AMPK/CREB signaling. Cells 2019, 8, 760. [CrossRef]

34. Mosser, D.M.; Edwards, J.P. Exploring the full spectrum of macrophage activation. Nat. Rev. Immunol. 2008, 8, 958-969. [CrossRef]

35. Garaschuk, O. Age-related changes in microglial physiology: The role for healthy brain ageing and neurodegenerative disorders. Neuroforum 2017, 23, A182-A191. [CrossRef]

36. Koellhoffer, E.C.; McCullough, L.D.; Ritzel, R.M. Old maids: Aging and its impact on microglia function. Int. J. Mol. Sci. 2017, 18, 769. [CrossRef]

37. Sierra, A.; Gottfried-Blackmore, A.C.; McEwen, B.S.; Bulloch, K. Microglia derived from aging mice exhibit an altered inflammatory profile. Glia 2007, 55, 412-424. [CrossRef]

38. Boelen, E.; Stassen, F.R.; Steinbusch, H.W.; Borchelt, D.R.; Streit, W.J. Ex vivo cultures of microglia from young and aged rodent brain reveal age-related changes in microglial function. Neurobiol. Aging 2012, 33, 195.e1-e12.

39. Qin, C.; Zhou, L.-Q.; Ma, X.-T.; Hu, Z.-W.; Yang, S.; Chen, M.; Bosco, D.B.; Wu, L.-J.; Tian, D.-S. Dual functions of microglia in ischemic stroke. Neurosci. Bull. 2019, 1-13. [CrossRef]

40. Savitz, S.I. Developing Cellular Therapies for Stroke. Stroke 2015, 46, 2026-2031. [CrossRef]

41. Jiang, X.; Andjelkovic, A.V.; Zhu, L.; Yang, T.; Bennett, M.V.; Chen, J.; Keep, R.F.; Shi, Y. Blood-brain barrier dysfunction and recovery after ischemic stroke. Prog. Neurobiol. 2018, 163, 144-171. [CrossRef] [PubMed]

42. Gülke, E.; Gelderblom, M.; Magnus, T. Danger signals in stroke and their role on microglia activation after ischemia. Ther. Adv. Neurol. Disord. 2018, 11. [CrossRef] [PubMed]

43. Abdullahi, W.; Tripathi, D.; Ronaldson, P.T. Blood-brain barrier dysfunction in ischemic stroke: Targeting tight junctions and transporters for vascular protection. Am. J. Physiol. Cell Physiol. 2018, 315, C343-C356. [CrossRef] [PubMed]

44. Busch, D.R.; Balu, R.; Baker, W.B.; Guo, W.; He, L.; Diop, M.; Milej, D.; Kavuri, V.; Amendolia, O.; Lawrence, K.S. Detection of brain hypoxia based on noninvasive optical monitoring of cerebral blood flow with diffuse correlation spectroscopy. Neurocrit. Care 2019, 30, 72-80. [CrossRef] [PubMed]

45. Lu, X.; Meng, L.; Zhou, Y.; Wang, S.; Fawaz, M.; Wang, M.; Haacke, E.M.; Chai, C.; Zheng, M.; Zhu, J. Quantitative susceptibilityweighted imaging may be an accurate method for determining stroke hypoperfusion and hypoxia of penumbra. Eur. Radiol. 2021, 1-11. [CrossRef]

46. Zhang, R.L.; Chopp, M.; Roberts, C.; Liu, X.; Wei, M.; Nejad-Davarani, S.P.; Wang, X.; Zhang, Z.G. Stroke increases neural stem cells and angiogenesis in the neurogenic niche of the adult mouse. PLoS ONE 2014, 9, e113972. [CrossRef] [PubMed]

47. Miller, F.D.; Gauthier-Fisher, A. Home at last: Neural stem cell niches defined. Cell Stem Cell 2009, 4, 507-510. [CrossRef]

48. Shah, P.T.; Stratton, J.A.; Stykel, M.G.; Abbasi, S.; Sharma, S.; Mayr, K.A.; Koblinger, K.; Whelan, P.J.; Biernaskie, J. Single-cell transcriptomics and fate mapping of ependymal cells reveals an absence of neural stem cell function. Cell 2018, 173, 1045-1057.e9.

49. Saenger, A.K.; Christenson, R.H. Stroke biomarkers: Progress and challenges for diagnosis, prognosis, differentiation, and treatment. Clin. Chem. 2010, 56, 21-33. [CrossRef]

50. Rothstein, L.; Jickling, G.C. Ischemic stroke biomarkers in blood. Biomark. Med. 2013, 7, 37-47. [CrossRef]

51. Makris, K.; Haliassos, A.; Chondrogianni, M.; Tsivgoulis, G. Blood biomarkers in ischemic stroke: Potential role and challenges in clinical practice and research. Crit. Rev. Clin. Lab. Sci. 2018, 55, 294-328. [CrossRef]

52. Krishnan, A.; Wu, H.; Venkataraman, V. Astrocytic S100B, Blood-Brain Barrier and Neurodegenerative Diseases. In Glia in Health and Disease; IntechOpen: London, UK, 2020.

53. Rose, C.R.; Felix, L.; Zeug, A.; Dietrich, D.; Reiner, A.; Henneberger, C. Astroglial glutamate signaling and uptake in the hippocampus. Front. Mol. Neurosci. 2018, 10, 451. [CrossRef]

54. Wang, K.K.; Yang, Z.; Zhu, T.; Shi, Y.; Rubenstein, R.; Tyndall, J.A.; Manley, G.T. An update on diagnostic and prognostic biomarkers for traumatic brain injury. Expert Rev. Mol. Diagn. 2018, 18, 165-180. [CrossRef]

55. Michetti, F.; D'Ambrosi, N.; Toesca, A.; Puglisi, M.A.; Serrano, A.; Marchese, E.; Corvino, V.; Geloso, M.C. The S100B story: From biomarker to active factor in neural injury. J. Neurochem. 2019, 148, 168-187. [CrossRef]

56. Li, D.; Liu, X.; Liu, T.; Liu, H.; Tong, L.; Jia, S.; Wang, Y.F. Neurochemical regulation of the expression and function of glial fibrillary acidic protein in astrocytes. Glia 2020, 68, 878-897. [CrossRef]

57. Sarfo, F.S.; Owusu, D.; Adamu, S.; Awuah, D.; Appiah, L.; Amamoo, M.; Loglo, A.; Owolabi, M.; Ovbiagele, B. Plasma glial fibrillary acidic protein, copeptin, and matrix metalloproteinase-9 concentrations among West African stroke subjects compared with stroke-free controls. J. Stroke Cerebrovasc. Dis. 2018, 27, 633-644. [CrossRef]

58. Chmielewska, N.; Szyndler, J.; Makowska, K.; Wojtyna, D.; Maciejak, P.; Płaźnik, A. Looking for novel, brain-derived, peripheral biomarkers of neurological disorders. Neurol. Neurochir. Pol. 2018, 52, 318-325. [CrossRef] 
59. Esnafoglu, E.; Ayyıldız, S.N.; Cırrık, S.; Erturk, E.Y.; Erdil, A.; Daglı, A.; Noyan, T. Evaluation of serum Neuron-specific enolase, $\mathrm{S} 100 \mathrm{~B}$, myelin basic protein and glial fibrilliary acidic protein as brain specific proteins in children with autism spectrum disorder. Int. J. Dev. Neurosci. 2017, 61, 86-91. [CrossRef]

60. Mahan, M.Y.; Thorpe, M.; Ahmadi, A.; Abdallah, T.; Casey, H.; Sturtevant, D.; Judge-Yoakam, S.; Hoover, C.; Rafter, D.; Miner, J. Glial fibrillary acidic protein (GFAP) outperforms S100 calcium-binding protein B (S100B) and ubiquitin C-terminal hydrolase L1 (UCH-L1) as predictor for positive computed tomography of the head in trauma subjects. World Neurosurg. 2019, 128, e434-e444. [CrossRef]

61. Shaik, A.J.; Reddy, K.; Mohammed, N.; Tandra, S.R.; Kss, S.B. Neuron specific enolase as a marker of seizure related neuronal injury. Neurochem. Int. 2019, 131, 104509. [CrossRef]

62. Park, S.-H.; Hwang, S.-K. Prognostic value of serum levels of S100 calcium-binding protein B, neuron-specific enolase, and interleukin-6 in pediatric patients with traumatic brain injury. World Neurosurg. 2018, 118, e534-e542. [CrossRef]

63. Lee, J.; Park, A.; Mun, S.; Kim, H.-J.; Son, H.; Choi, H.; Kim, D.; Lee, S.J.; Kim, J.G.; Kang, H.-G. Proteomics-based identification of diagnostic biomarkers related to risk factors and pathogenesis of ischemic stroke. Diagnostics 2020, 10, 340. [CrossRef]

64. Induruwa, I.; Moroi, M.; Bonna, A.; Malcor, J.D.; Howes, J.M.; Warburton, E.; Farndale, R.; Jung, S. Platelet collagen receptor Glycoprotein VI-dimer recognizes fibrinogen and fibrin through their D-domains, contributing to platelet adhesion and activation during thrombus formation. J. Thromb. Haemost. 2018, 16, 389-404. [CrossRef] [PubMed]

65. Shah, P.; Tantry, U.S.; Bliden, K.P.; Gurbel, P.A. Bleeding and thrombosis associated with ventricular assist device therapy. J. Heart Lung Transplant. 2017, 36, 1164-1173. [CrossRef] [PubMed]

66. Laskowitz, D.T.; Blessing, R.; Floyd, J.; White, W.D.; Lynch, J.R. Panel of biomarkers predicts stroke. Ann. N. Y. Acad. Sci. 2005, 1053, 30. [CrossRef] [PubMed]

67. Zhang, R.; Xu, M.; Wang, Y.; Xie, F.; Zhang, G.; Qin, X. Nrf2-A promising therapeutic target for defensing against oxidative stress in stroke. Mol. Neurobiol. 2017, 54, 6006-6017. [CrossRef] [PubMed]

68. Sun, M.-S.; Jin, H.; Sun, X.; Huang, S.; Zhang, F.-L.; Guo, Z.-N.; Yang, Y. Free radical damage in ischemia-reperfusion injury: An obstacle in acute ischemic stroke after revascularization therapy. Oxidative Med. Cell. Longev. 2018, 2018. [CrossRef]

69. Chang, J.-C.; Lien, C.-F.; Lee, W.-S.; Chang, H.-R.; Hsu, Y.-C.; Luo, Y.-P.; Jeng, J.-R.; Hsieh, J.-C.; Yang, K.-T. Intermittent hypoxia prevents myocardial mitochondrial $\mathrm{Ca}^{2+}$ overload and cell death during ischemia/reperfusion: The role of reactive oxygen species. Cells 2019, 8, 564. [CrossRef]

70. Yang, M.; Linn, B.S.; Zhang, Y.; Ren, J. Mitophagy and mitochondrial integrity in cardiac ischemia-reperfusion injury. Biochim. Biophys. Acta (BBA) Mol. Basis Dis. 2019, 1865, 2293-2302. [CrossRef]

71. Davidson, S.M.; Adameová, A.; Barile, L.; Cabrera-Fuentes, H.A.; Lazou, A.; Pagliaro, P.; Stensløkken, K.O.; Garcia-Dorado, D.; Action, E.C.C. Mitochondrial and mitochondrial-independent pathways of myocardial cell death during ischaemia and reperfusion injury. J. Cell. Mol. Med. 2020, 24, 3795-3806. [CrossRef]

72. Liu, H.; Uno, M.; Kitazato, K.T.; Suzue, A.; Manabe, S.; Yamasaki, H.; Shono, M.; Nagahiro, S. Peripheral oxidative biomarkers constitute a valuable indicator of the severity of oxidative brain damage in acute cerebral infarction. Brain Res. 2004, 1025, 43-50. [CrossRef]

73. Brea, D.; Roquer, J.; Serena, J.; Segura, T.; Castillo, J.; Artico, S. Oxidative stress markers are associated to vascular recurrence in non-cardioembolic stroke patients non-treated with statins. BMC Neurol. 2012, 12, 65. [CrossRef]

74. Woodruff, T.M.; Thundyil, J.; Tang, S.C.; Sobey, C.G.; Taylor, S.M.; Arumugam, T.V. Pathophysiology, treatment, and animal and cellular models of human ischemic stroke. Mol. Neurodegener. 2011, 6, 11. [CrossRef]

75. Zagrean, A.-M.; Hermann, D.M.; Opris, I.; Zagrean, L.; Popa-Wagner, A. Multicellular crosstalk between exosomes and the neurovascular unit after cerebral ischemia. Therapeutic implications. Front. Neurosci. 2018, 12, 811. [CrossRef]

76. Pawluk, H.; Woźniak, A.; Grześk, G.; Kołodziejska, R.; Kozakiewicz, M.; Kopkowska, E.; Grzechowiak, E.; Kozera, G. The role of selected pro-inflammatory cytokines in pathogenesis of ischemic stroke. Clin. Interv. Aging 2020, 15, 469. [CrossRef]

77. Alhazzani, A.; Rajagopalan, P.; Albarqi, Z.; Devaraj, A.; Mohamed, M.H.; Al-Hakami, A.; Chandramoorthy, H.C. Mesenchymal stem cells (MSCs) coculture protects [Ca2+] i orchestrated oxidant mediated damage in differentiated neurons . Cells 2018, 7, 250. [CrossRef]

78. Mergenthaler, P.; Dirnagl, U.; Meisel, A. Pathophysiology of stroke: Lessons from animal models. Metab. Brain Dis. 2004, 19, 151-167. [CrossRef]

79. Marei, H.E.; Hasan, A.; Rizzi, R.; Althani, A.; Afifi, N.; Cenciarelli, C.; Caceci, T.; Shuaib, A. Potential of stem cell-based therapy for ischemic stroke. Front. Neurol. 2018, 9, 34. [CrossRef]

80. Zhu, S.-Z.; Szeto, V.; Bao, M.-H.; Sun, H.-S.; Feng, Z.-P. Pharmacological approaches promoting stem cell-based therapy following ischemic stroke insults. Acta Pharmacol. Sin. 2018, 39, 695-712. [CrossRef]

81. Chau, M.; Deveau, T.C.; Song, M.; Wei, Z.Z.; Gu, X.; Yu, S.P.; Wei, L. Transplantation of iPS cell-derived neural progenitors overexpressing SDF-1 $\alpha$ increases regeneration and functional recovery after ischemic stroke. Oncotarget 2017, 8, 97537. [CrossRef]

82. Webb, R.L.; Kaiser, E.E.; Scoville, S.L.; Thompson, T.A.; Fatima, S.; Pandya, C.; Sriram, K.; Swetenburg, R.L.; Vaibhav, K.; Arbab, A.S. Human neural stem cell extracellular vesicles improve tissue and functional recovery in the murine thromboembolic stroke model. Transl. Stroke Res. 2018, 9, 530-539. [CrossRef] [PubMed] 
83. Peng, J.-J.; Sha, R.; Li, M.-X.; Chen, L.-T.; Han, X.-H.; Guo, F.; Chen, H.; Huang, X.-L. Repetitive transcranial magnetic stimulation promotes functional recovery and differentiation of human neural stem cells in rats after ischemic stroke. Exp. Neurol. 2019, 313, 1-9. [CrossRef] [PubMed]

84. Geng, W.; Tang, H.; Luo, S.; Lv, Y.; Liang, D.; Kang, X.; Hong, W. Exosomes from miRNA-126-modified ADSCs promotes functional recovery after stroke in rats by improving neurogenesis and suppressing microglia activation. Am. J. Transl. Res. 2019, 11,780 .

85. Lee, J.P.; Jeyakumar, M.; Gonzalez, R.; Takahashi, H.; Lee, P.J.; Baek, R.C.; Clark, D.; Rose, H.; Fu, G.; Clarke, J.; et al. Stem cells act through multiple mechanisms to benefit mice with neurodegenerative metabolic disease. Nat. Med. 2007, 13, 439-447. [CrossRef]

86. Daadi, M.M.; Steinberg, G.K. Manufacturing neurons from human embryonic stem cells: Biological and regulatory aspects to develop a safe cellular product for stroke cell therapy. Regen. Med. 2009, 4, 251-263. [CrossRef]

87. Bliss, T.; Guzman, R.; Daadi, M.; Steinberg, G.K. Cell transplantation therapy for stroke. Stroke 2007, 38, 817-826. [CrossRef]

88. Aked, J.; Delavaran, H.; Lindvall, O.; Norrving, B.; Kokaia, Z.; Lindgren, A. Attitudes to Stem Cell Therapy among Ischemic Stroke Survivors in the Lund Stroke Recovery Study. Stem Cells Dev. 2017. [CrossRef]

89. Huang, L.; Liu, Y.; Lu, J.; Cerqueira, B.; Misra, V.; Duong, T.Q. Intraarterial transplantation of human umbilical cord blood mononuclear cells in hyperacute stroke improves vascular function. Stem Cell Res. Ther. 2017, 8, 74. [CrossRef]

90. Zhao, K.; Li, R.; Gu, C.; Liu, L.; Jia, Y.; Guo, X.; Zhang, W.; Pei, C.; Tian, L.; Li, B.; et al. Intravenous Administration of Adipose-Derived Stem Cell Protein Extracts Improves Neurological Deficits in a Rat Model of Stroke. Stem Cells Int. 2017, 2017, 2153629. [CrossRef]

91. Liang, X.; Ding, Y.; Zhang, Y.; Tse, H.F.; Lian, Q. Paracrine mechanisms of mesenchymal stem cell-based therapy: Current status and perspectives. Cell Transpl. 2014, 23, 1045-1059. [CrossRef]

92. Garbuzova-Davis, S.; Haller, E.; Lin, R.; Borlongan, C.V. Intravenously Transplanted Human Bone Marrow Endothelial Progenitor Cells Engraft Within Brain Capillaries, Preserve Mitochondrial Morphology, and Display Pinocytotic Activity Toward Blood-Brain Barrier Repair in Ischemic Stroke Rats. Stem Cells 2017. [CrossRef]

93. Yang, B.; Hamilton, J.A.; Valenzuela, K.S.; Bogaerts, A.; Xi, X.; Aronowski, J.; Mays, R.W.; Savitz, S.I. Multipotent Adult Progenitor Cells Enhance Recovery After Stroke by Modulating the Immune Response from the Spleen. Stem Cells 2017. [CrossRef]

94. Lee, S.R.; Lee, H.J.; Cha, S.H.; Jeong, K.J.; Lee, Y.; Jeon, C.Y.; Yi, K.S.; Lim, I.; Cho, Z.H.; Chang, K.T.; et al. Long-term survival and differentiation of human neural stem cells in nonhuman primate brain with no immunosuppression. Cell Transpl. 2015, 24, 191-201. [CrossRef]

95. Song, M.; Kim, Y.J.; Kim, Y.H.; Roh, J.; Kim, E.C.; Lee, H.J.; Kim, S.U.; Yoon, B.W. Long-term effects of magnetically targeted ferumoxide-labeled human neural stem cells in focal cerebral ischemia. Cell Transpl. 2015, 24, 183-190. [CrossRef]

96. Qin, J.; Ma, X.; Qi, H.; Song, B.; Wang, Y.; Wen, X.; Wang, Q.M.; Sun, S.; Li, Y.; Zhang, R.; et al. Transplantation of Induced Pluripotent Stem Cells Alleviates Cerebral Inflammation and Neural Damage in Hemorrhagic Stroke. PLoS ONE 2015, 10, e0129881. [CrossRef]

97. Herberts, C.A.; Kwa, M.S.; Hermsen, H.P. Risk factors in the development of stem cell therapy. J. Transl. Med. $2011,9,29$. [CrossRef]

98. Zhang, J.; Chopp, M. Cell-based therapy for ischemic stroke. Expert Opin. Biol. Ther. 2013, 13, 1229-1240. [CrossRef]

99. Xin, H.; Li, Y.; Cui, Y.; Yang, J.J.; Zhang, Z.G.; Chopp, M. Systemic administration of exosomes released from mesenchymal stromal cells promote functional recovery and neurovascular plasticity after stroke in rats. J. Cereb. Blood Flow Metab. 2013, 33, 1711-1715. [CrossRef]

100. Collino, F.; Deregibus, M.C.; Bruno, S.; Sterpone, L.; Aghemo, G.; Viltono, L.; Tetta, C.; Camussi, G. Microvesicles derived from adult human bone marrow and tissue specific mesenchymal stem cells shuttle selected pattern of miRNAs. PLoS ONE 2010, 5, e11803. [CrossRef]

101. Zhang, Y.; Bi, J.; Huang, J.; Tang, Y.; Du, S.; Li, P. Exosome: A review of its classification, isolation techniques, storage, diagnostic and targeted therapy applications. Int. J. Nanomed. 2020, 15, 6917. [CrossRef]

102. He, C.; Zheng, S.; Luo, Y.; Wang, B. Exosome theranostics: Biology and translational medicine. Theranostics 2018, 8, 237. [CrossRef] [PubMed]

103. Doeppner, T.R.; Herz, J.; Gorgens, A.; Schlechter, J.; Ludwig, A.K.; Radtke, S.; de Miroschedji, K.; Horn, P.A.; Giebel, B.; Hermann, D.M. Extracellular Vesicles Improve Post-Stroke Neuroregeneration and Prevent Postischemic Immunosuppression. Stem Cells Transl. Med. 2015, 4, 1131-1143. [CrossRef] [PubMed]

104. Kim, D.K.; Nishida, H.; An, S.Y.; Shetty, A.K.; Bartosh, T.J.; Prockop, D.J. Chromatographically isolated CD63+CD81+ extracellular vesicles from mesenchymal stromal cells rescue cognitive impairments after TBI. Proc. Natl. Acad. Sci. USA 2016, 113, 170-175. [CrossRef] [PubMed]

105. Xin, H.; Li, Y.; Chopp, M. Exosomes/miRNAs as mediating cell-based therapy of stroke. Front. Cell. Neurosci. $2014,8,377$. [CrossRef]

106. Zhang, Y.; Chopp, M.; Liu, X.S.; Katakowski, M.; Wang, X.; Tian, X.; Wu, D.; Zhang, Z.G. Exosomes Derived from Mesenchymal Stromal Cells Promote Axonal Growth of Cortical Neurons. Mol. Neurobiol. 2016. [CrossRef]

107. Zhang, Z.G.; Chopp, M. Promoting brain remodeling to aid in stroke recovery. Trends Mol. Med. 2015, 21, 543-548. [CrossRef]

108. Reza-Zaldivar, E.E.; Hernández-Sapiéns, M.A.; Minjarez, B.; Gutiérrez-Mercado, Y.K.; Márquez-Aguirre, A.L.; Canales-Aguirre, A.A. Potential effects of MSC-derived exosomes in neuroplasticity in Alzheimer's disease. Front. Cell. Neurosci. 2018, 12, 317. [CrossRef] 
109. Roundtable, S.T.A.I. Recommendations for standards regarding preclinical neuroprotective and restorative drug development. Stroke 1999, 30, 2752-2758.

110. Cook, D.J.; Tymianski, M. Nonhuman primate models of stroke for translational neuroprotection research. Neurotherapeutics 2012, 9, 371-379. [CrossRef]

111. Gervois, P.; Wolfs, E.; Ratajczak, J.; Dillen, Y.; Vangansewinkel, T.; Hilkens, P.; Bronckaers, A.; Lambrichts, I.; Struys, T. Stem cell-based therapies for ischemic stroke: Preclinical results and the potential of imaging-assisted evaluation of donor cell fate and mechanisms of brain regeneration. Med. Res. Rev. 2016, 36, 1080-1126. [CrossRef]

112. Xie, F.; Liu, H.; Liu, Y. Adult Neurogenesis Following Ischemic Stroke and Implications for Cell-Based Therapeutic Approaches. World Neurosurg. 2020, 138, 474-480. [CrossRef]

113. Hopfer, M.; Planas, R.; Hamidipour, A.; Henriksson, T.; Semenov, S. Electromagnetic Tomography for Detection, Differentiation, and Monitoring of Brain Stroke: A Virtual Data and Human Head Phantom Study. IEEE Antennas Propag. Mag. 2017, 59, 86-97. [CrossRef]

114. Zhang, F.; Duan, X.; Lu, L.; Zhang, X.; Chen, M.; Mao, J.; Cao, M.; Shen, J. In vivo long-term tracking of neural stem cells transplanted into an acute ischemic stroke model with reporter gene-based bimodal MR and optical imaging. Cell Transpl. 2017, 26, 1648-1662. [CrossRef]

115. Aswendt, M.; Adamczak, J.; Tennstaedt, A. A review of novel optical imaging strategies of the stroke pathology and stem cell therapy in stroke. Front Cell Neurosci. 2014, 8, 226. [CrossRef]

116. Kondori, B.J.; Asadi, M.; Bahadoran, H.; Yari, A.; Raouf Sarshoori, J. Intra-arterial transplantation of neural stem cells improve functional recovery after transient ischemic stroke in adult rats. Bratisl. Med. J. 2020, 121, 8-13. [CrossRef]

117. Park, H.W.; Kim, Y.; Chang, J.W.; Yang, Y.S.; Oh, W.; Lee, J.M.; Park, H.R.; Kim, D.G.; Paek, S.H. Effect of Single and Double Administration of Human Umbilical Cord Blood-Derived Mesenchymal Stem Cells Following Focal Cerebral Ischemia in Rats. Exp. Neurobiol. 2017, 26, 55-65. [CrossRef]

118. Song, S.; Huang, H.; Guan, X.; Fiesler, V.; Bhuiyan, M.I.H.; Liu, R.; Jalali, S.; Hasan, M.N.; Tai, A.K.; Chattopadhyay, A. Activation of endothelial Wnt/ $\beta$-catenin signaling by protective astrocytes repairs BBB damage in ischemic stroke. Prog. Neurobiol. 2020, 101963. [CrossRef]

119. Argibay, B.; Trekker, J.; Himmelreich, U.; Beiras, A.; Topete, A.; Taboada, P.; Perez-Mato, M.; Vieites-Prado, A.; Iglesias-Rey, R.; Rivas, J.; et al. Intraarterial route increases the risk of cerebral lesions after mesenchymal cell administration in animal model of ischemia. Sci. Rep. 2017, 7, 40758. [CrossRef]

120. Boese, A.C.; Le, Q.-S.E.; Pham, D.; Hamblin, M.H.; Lee, J.-P. Neural stem cell therapy for subacute and chronic ischemic stroke. Stem Cell Res. Ther. 2018, 9, 1-17. [CrossRef]

121. Bacigaluppi, M.; Russo, G.L.; Peruzzotti-Jametti, L.; Rossi, S.; Sandrone, S.; Butti, E.; De Ceglia, R.; Bergamaschi, A.; Motta, C.; Gallizioli, M. Neural stem cell transplantation induces stroke recovery by upregulating glutamate transporter GLT-1 in astrocytes. J. Neurosci. 2016, 36, 10529-10544. [CrossRef]

122. Ham, O.; Jin, Y.B.; Kim, J.; Lee, M.-O. Blood vessel formation in cerebral organoids formed from human embryonic stem cells. Biochem. Biophys. Res. Commun. 2020, 521, 84-90. [CrossRef]

123. Moxon, S.R.; Corbett, N.J.; Fisher, K.; Potjewyd, G.; Domingos, M.; Hooper, N.M. Blended alginate/collagen hydrogels promote neurogenesis and neuronal maturation. Mater. Sci. Eng. C 2019, 104, 109904. [CrossRef]

124. Lim, S.; Yoon, H.Y.; Jang, H.J.; Song, S.; Kim, W.; Park, J.; Lee, K.E.; Jeon, S.; Lee, S.; Lim, D.-K. Dual-Modal imaging-guided precise tracking of Bioorthogonally labeled mesenchymal stem cells in mouse brain stroke. ACS Nano 2019, 13, 10991-11007. [CrossRef]

125. Ding, J.; Zhang, Y.; Wang, C.-X.; Li, P.-C.; Zhao, Z.; Wang, C.; Teng, G.-J. Dual-modality imaging of endothelial progenitor cells transplanted after ischaemic photothrombotic stroke. Life Sci. 2019, 239, 116774. [CrossRef]

126. Werden, E.; Cumming, T.; Li, Q.; Bird, L.; Veldsman, M.; Pardoe, H.R.; Jackson, G.; Donnan, G.A.; Brodtmann, A. Structural MRI markers of brain aging early after ischemic stroke. Neurology 2017, 89, 116-124. [CrossRef] [PubMed]

127. Li, M.; Zhao, Y.; Zhan, Y.; Yang, L.; Feng, X.; Lu, Y.; Lei, J.; Zhao, T.; Wang, L.; Zhao, H. Enhanced white matter reorganization and activated brain glucose metabolism by enriched environment following ischemic stroke: Micro PET/CT and MRI study. Neuropharmacology 2020, 176, 10820. [CrossRef] [PubMed]

128. Zhang, H.; Song, F.; Xu, C.; Liu, H.; Wang, Z.; Li, J.; Wu, S.; Yehua, S.; Chen, Y.; Zhu, Y.; et al. Spatiotemporal PET Imaging of Dynamic Metabolic Changes After Therapeutic Approaches of Induced Pluripotent Stem Cells, Neuronal Stem Cells, and a Chinese Patent Medicine in Stroke. J. Nucl. Med. 2015, 56, 1774-1779. [CrossRef] [PubMed]

129. Qiao, Y.; Gumin, J.; MacLellan, C.J.; Gao, F.; Bouchard, R.; Lang, F.F.; Stafford, R.J.; Melancon, M.P. Magnetic resonance and photoacoustic imaging of brain tumor mediated by mesenchymal stem cell labeled with multifunctional nanoparticle introduced via carotid artery injection. Nanotechnology 2018, 29, 165101. [CrossRef]

130. Nucci, M.P.; Filgueiras, I.S.; Ferreira, J.M.; de Oliveira, F.A.; Nucci, L.P.; Mamani, J.B.; Rego, G.N.A.; Gamarra, L.F. Stem cell homing, tracking and therapeutic efficiency evaluation for stroke treatment using nanoparticles: A systematic review. World J. Stem Cells 2020, 12, 381. [CrossRef]

131. Azevedo-Pereira, R.L.; Rangel, B.; Tovar-Moll, F.; Gasparetto, E.L.; Attias, M.; Zaverucha-do-Valle, C.; Mendez-Otero, R. Superparamagnetic iron oxide nanoparticles as a tool to track mouse neural stem cells . Mol. Biol. Rep. 2019, 46, 191-198. [CrossRef] 
132. Li, J.; Feng, Z.; Gu, N.; Yang, F. Superparamagnetic iron oxide nanoparticles assembled magnetic nanobubbles and their application for neural stem cells labeling. J. Mater. Sci. Technol. 2021, 63, 124-132. [CrossRef]

133. Kim, S.-K.; Lee, D.-K.; Lim, H.-J.; Sim, U. In vitro targeting and imaging of neurogenic differentiation in mouse bone-marrow derived mesenchymal stem cells with superparamagnetic iron oxide nanoparticles. Appl. Sci. 2019, 9, 3259. [CrossRef]

134. Yao, D.; Liu, N.-N.; Mo, B.-W. Assessment of proliferation, migration and differentiation potentials of bone marrow mesenchymal stem cells labeling with silica-coated and amine-modified superparamagnetic iron oxide nanoparticles. Cytotechnology 2020, 72, 513-525. [CrossRef]

135. Zhu, L.-L.; Zhang, Z.; Jiang, H.-S.; Chen, H.; Chen, Y.; Dai, Y.-T. Superparamagnetic iron oxide nanoparticle targeting of adipose tissue-derived stem cells in diabetes-associated erectile dysfunction. Asian J. Androl. 2017, 19, 425. [CrossRef]

136. Hsu, F.-T.; Wei, Z.-H.; Hsuan, Y.C.-Y.; Lin, W.; Su, Y.-C.; Liao, C.-H.; Hsieh, C.-L. MRI tracking of polyethylene glycol-coated superparamagnetic iron oxide-labelled placenta-derived mesenchymal stem cells toward glioblastoma stem-like cells in a mouse model. Artif. Cells Nanomed. Biotechnol. 2018, 46, S448-S459. [CrossRef]

137. Yang, D.; Xi, J.; Xing, Y.; Tang, X.; Dai, X.; Li, K.; Li, H.; Lv, X.; Lu, D.; Wang, H. A new method for neonatal rat ventricular myocyte purification using superparamagnetic iron oxide particles. Int. J. Cardiol. 2018, 270, 293-301. [CrossRef]

138. Kang, M.K.; Kim, T.J.; Kim, Y.-J.; Kang, L.; Kim, J.; Lee, N.; Hyeon, T.; Lim, M.-S.; Mo, H.J.; Shin, J.H. Targeted Delivery of Iron Oxide Nanoparticle-Loaded Human Embryonic Stem Cell-Derived Spherical Neural Masses for Treating Intracerebral Hemorrhage. Int. J. Mol. Sci. 2020, 21, 3658. [CrossRef]

139. Li, K.; Yamamoto, M.; Chan, S.J.; Chiam, M.Y.; Qin, W.; Wong, P.T.; Yim, E.K.; Tang, B.Z.; Liu, B. Organic nanoparticles with aggregation-induced emission for tracking bone marrow stromal cells in the rat ischemic stroke model. Chem. Commun. 2014, 50, 15136-15139. [CrossRef]

140. Cai, X.; Zhang, C.J.; Ting Wei Lim, F.; Chan, S.J.; Bandla, A.; Chuan, C.K.; Hu, F.; Xu, S.; Thakor, N.V.; Liao, L.D.; et al. Organic Nanoparticles with Aggregation-Induced Emission for Bone Marrow Stromal Cell Tracking in a Rat PTI Model. Small 2016, 12, 6576-6585. [CrossRef]

141. Ferreira, R.; Fonseca, M.C.; Santos, T.; Sargento-Freitas, J.; Tjeng, R.; Paiva, F.; Castelo-Branco, M.; Ferreira, L.S.; Bernardino, L. Retinoic acid-loaded polymeric nanoparticles enhance vascular regulation of neural stem cell survival and differentiation after ischaemia. Nanoscale 2016, 8, 8126-8137. [CrossRef]

142. Petro, M.; Jaffer, H.; Yang, J.; Kabu, S.; Morris, V.B.; Labhasetwar, V. Tissue plasminogen activator followed by antioxidant-loaded nanoparticle delivery promotes activation/mobilization of progenitor cells in infarcted rat brain. Biomaterials 2016, 81, 169-180. [CrossRef] [PubMed]

143. Kim, D.H.; Seo, Y.K.; Thambi, T.; Moon, G.J.; Son, J.P.; Li, G.; Park, J.H.; Lee, J.H.; Kim, H.H.; Lee, D.S.; et al. Enhancing neurogenesis and angiogenesis with target delivery of stromal cell derived factor-1alpha using a dual ionic $\mathrm{pH}$-sensitive copolymer. Biomaterials 2015, 61, 115-125. [CrossRef] [PubMed]

144. Iijima, N.; Miyamoto, S.; Matsumoto, K.; Takumi, K.; Ueta, Y.; Ozawa, H. Development of an imaging system for real-time monitoring of neuronal activity in deep brain of free-moving rats. Histochem. Cell Biol. 2017, 148, 289-298. [CrossRef] [PubMed]

145. Campbell, B.C.; Nabel, E.M.; Murdock, M.H.; Lao-Peregrin, C.; Tsoulfas, P.; Blackmore, M.G.; Lee, F.S.; Liston, C.; Morishita, H.; Petsko, G.A. mGreenLantern: A bright monomeric fluorescent protein with rapid expression and cell filling properties for neuronal imaging. Proc. Natl. Acad. Sci. USA 2020, 117, 30710-30721. [CrossRef]

146. Lischik, C.Q.; Adelmann, L.; Wittbrodt, J. Enhanced in vivo-imaging in medaka by optimized anaesthesia, fluorescent protein selection and removal of pigmentation. PLOS ONE 2019, 14, e0212956. [CrossRef]

147. Dou, L.; Matz, E.L.; Gu, X.; Shu, F.; Paxton, J.; Song, J.; Yoo, J.; Atala, A.; Jackson, J.; Zhang, Y. Non-invasive cell tracking with brighter and red-transferred luciferase for potential application in stem cell therapy. Cell Transplant. 2019, 28, 1542-1551. [CrossRef]

148. Komatsu, H.; Gonzalez, N.; Ortiz, J.; Rawson, J.; Omori, K.; Kandeel, F.; Mullen, Y. Early-Phase Luciferase Signals of Islet Grafts Predicts Successful Subcutaneous Site Transplantation in Rats. Mol. Imaging Biol. 2020, 1-7. [CrossRef]

149. Zare, S.; Mehrabani, D.; Jalli, R.; Saeedi Moghadam, M.; Manafi, N.; Mehrabani, G.; Jamhiri, I.; Ahadian, S. MRI-tracking of dental pulp stem cells and using dextran-coated superparamagnetic iron oxide nanoparticles. J. Clin. Med. 2019, 8, 1418. [CrossRef]

150. Quang, H.V.; Chang, C.-C.; Song, P.; Hauge, E.-M.; Kjems, J. Caveolae-mediated mesenchymal stem cell labelling by PSS-coated PLGA PFOB nano-contrast agent for MRI. Theranostics 2018, 8, 2657. [CrossRef]

151. Lu, M.; Cheng, X.; Jiang, J.; Li, T.; Zhang, Z.; Tsauo, C.; Liu, Y.; Wang, Z. Dual-modal photoacoustic and magnetic resonance tracking of tendon stem cells with PLGA/iron oxide microparticles. PLoS ONE 2018, 13, e0193362. [CrossRef]

152. Foerch, C.; Singer, O.C.; Neumann-Haefelin, T.; de Rochemont, R.d.M.; Steinmetz, H.; Sitzer, M. Evaluation of serum S100B as a surrogate marker for long-term outcome and infarct volume in acute middle cerebral artery infarction. Arch. Neurol. 2005, 62, 1130-1134 [CrossRef]

153. Zhou, S.; Zhu, W.; Zhang, Y.; Pan, S.; Bao, J. S100B promotes microglia M1 polarization and migration to aggravate cerebral ischemia. Inflamm. Res. 2018, 67, 937-949. [CrossRef]

154. Abraha, H.D.; Butterworth, R.J.; Bath, P.M.; Wassif, W.S.; Garthwaite, J.; Sherwood, R.A. Serum S-100 protein, relationship to clinical outcome in acute stroke. Ann. Clin. Biochem. 1997, 34, 366-370. [CrossRef]

155. Ren, C.; Kobeissy, F.; Alawieh, A.; Li, N.; Li, N.; Zibara, K.; Zoltewicz, S.; Guingab-Cagmat, J.; Larner, S.F.; Ding, Y. Assessment of serum UCH-L1 and GFAP in acute stroke patients. Sci. Rep. 2016, 6, 1-9. [CrossRef] 
156. Luger, S.; Witsch, J.; Dietz, A.; Hamann, G.F.; Minnerup, J.; Schneider, H.; Sitzer, M.; Wartenberg, K.E.; Niessner, M.; Foerch, C. Glial fibrillary acidic protein serum levels distinguish between intracerebral hemorrhage and cerebral ischemia in the early phase of stroke. Clin. Chem. 2017, 63, 377-385. [CrossRef]

157. Jauch, E.C.; Lindsell, C.; Broderick, J.; Fagan, S.C.; Tilley, B.C.; Levine, S.R. Association of serial biochemical markers with acute ischemic stroke: The National Institute of Neurological Disorders and Stroke recombinant tissue plasminogen activator Stroke Study. Stroke 2006, 37, 2508-2513. [CrossRef]

158. Javidi, E.; Magnus, T. Autoimmunity after ischemic stroke and brain injury. Front. Immunol. 2019, 10, 686. [CrossRef]

159. Hill, M.D.; Jackowski, G.; Bayer, N.; Lawrence, M.; Jaeschke, R. Biochemical markers in acute ischemic stroke. CMAJ 2000, 162, $1139-1140$

160. Huţanu, A.; Iancu, M.; Bălaşa, R.; Maier, S.; Dobreanu, M. Predicting functional outcome of ischemic stroke patients in Romania based on plasma CRP, sTNFR-1, D-Dimers, NGAL and NSE measured using a biochip array. Acta Pharmacol. Sin. 2018, 39, 1228-1236. [CrossRef]

161. Dhanesha, N.; Chorawala, M.R.; Jain, M.; Bhalla, A.; Thedens, D.; Nayak, M.; Doddapattar, P.; Chauhan, A.K. Fn-EDA (fibronectin containing extra domain A) in the plasma, but not endothelial cells, exacerbates stroke outcome by promoting thrombo-inflammation. Stroke 2019, 50, 1201-1209. [CrossRef]

162. Castellanos, M.; Leira, R.; Serena, J.; Blanco, M.; Pedraza, S.; Castillo, J.; Dávalos, A. Plasma cellular-fibronectin concentration predicts hemorrhagic transformation after thrombolytic therapy in acute ischemic stroke. Stroke 2004, 35, 1671-1676. [CrossRef]

163. Barber, M.; Langhorne, P.; Rumley, A.; Lowe, G.D.; Stott, D.J. D-dimer predicts early clinical progression in ischemic stroke: Confirmation using routine clinical assays. Stroke 2006, 37, 1113-1115. [CrossRef] [PubMed]

164. Menih, M.; Križmarić, M.; Fabjan, T.H. Clinical role of von Willebrand factor in acute ischemic stroke. Wien. Klin. Wochenschr. 2017, 129, 491-496. [CrossRef] [PubMed]

165. De Meyer, S.F.; Stoll, G.; Wagner, D.D.; Kleinschnitz, C. von Willebrand factor: An emerging target in stroke therapy. Stroke 2012, 43, 599-606. [CrossRef] [PubMed]

166. Castellanos, M.; Sobrino, T.; Millan, M.; Garcia, M.A.; Arenillas, J.; Nombela, F.; Brea, D.; Perez de la Ossa, N.; Serena, J.N.; Vivancos, J. Serum cellular fibronectin and matrix metalloproteinase-9 as screening biomarkers for the prediction of parenchymal hematoma after thrombolytic therapy in acute ischemic stroke: A multicenter confirmatory study. Stroke 2007, 38, 1855-1859. [CrossRef]

167. Nhon, P.L. A2958 Assessement of biomarker complex: VWF, VCAM-1, MCP-1, D-DIMER in the diagnosis and prognosis of acute ischemic stroke. J. Hypertens. 2018, 36, e285. [CrossRef]

168. Lasek-Bal, A.; Jedrzejowska-Szypulka, H.; Student, S.; Warsz-Wianecka, A.; Zareba, K.; Puz, P.; Bal, W.; Pawletko, K.; Lewin-Kowalik, J. The importance of selected markers of inflammation and blood-brain barrier damage for short-term ischemic stroke prognosis. J. Physiol. Pharmacol. 2019, 70, 209-217

169. Hotter, B.; Hoffmann, S.; Ulm, L.; Meisel, C.; Fiebach, J.B.; Meisel, A. IL-6 plasma levels correlate with cerebral perfusion deficits and infarct sizes in stroke patients without associated infections. Front. Neurol. 2019, 10, 796-801. [CrossRef] 